\title{
GENERAL COMPOSITE ITERATIVE METHODS FOR GENERAL SYSTEMS OF VARIATIONAL INEQUALITIES
}

\author{
A. LATIF*, A.S.M. ALOFI**, A.E. AL-MAZROOEI*** AND J.C. YAO**** \\ *Department of Mathematics, King Abdulaziz University \\ P.O. Box 80203, Jeddah 21589, Saudi Arabia \\ E-mail: alatif@kau.edu.sa \\ ** Department of Mathematics, King Abdulaziz University \\ P.O. Box 80203, Jeddah 21589, Saudi Arabia \\ E-mail: aalofi1@kau.edu.sa \\ *** Department of Mathematics, University of Jeddah \\ P.O.Box 80327, Jeddah 21589, Saudi Arabia \\ E-mail: aealmazrooei@kau.edu.sa \\ ${ }^{* * * *, 1}$ Center for General Education, China Medical University \\ Taichung 40402, Taiwan; \\ and \\ Department of Mathematics, King Abdulaziz University \\ P.O. Box 80203, Jeddah 21589, Saudi Arabia \\ E-mail: yaojc@mail.cmu.edu.tw
}

\begin{abstract}
In this paper, we introduce a general composite implicit scheme and a general composite explicit scheme for finding a solution of general system of variational inequalities in a real Hilbert space. We establish the strong convergence of these two general composite schemes to a solution of the general system of variational inequalities which is the unique solution of some variational inequality. Applications to variational inequalities are given.

Key Words and Phrases: General composite iterative method, general system of variational inequalities, inverse-strongly monotone mapping, strictly pseudocontractive mapping, nonexpansive mapping, fixed point.
\end{abstract}

2010 Mathematics Subject Classification: 49J30, 47H09, 47J20, 49M05.

Acknowledgement. This project was funded by the Deanship of Scientific Research (DSR), King Abdulaziz University under grant no. (34-130-36-HiCi). The authors, therefore, acknowledge with thanks DSR technical and financial support.

\section{REFERENCES}

[1] B.A. Bin Dehaish, A. Latif, H.O. Bakodah, X. Qin, A viscosity splitting algorithm for solving inclusion and equilibrium problems, J. Ineq. Appl., 50(2015).

[2] L.C. Ceng, Q.H. Ansari, J.C. Yao, Relaxed extragradient iterative methods for variational inequalities, Appl. Math. Comput., 218(2011), 1112-1123.

\footnotetext{
${ }^{1}$ Corresponding author.
} 
[3] L.C. Ceng, Q.H. Ansari, J.C. Yao, Some iterative methods for finding fixed points and for solving constrained convex minimization problems, Nonlinear Anal., 74(2011), 5286-5302.

[4] L.C. Ceng, S.M. Guu, J.C. Yao, A general composite iterative algorithm for nonexpansive mappings in Hilbert spaces, Comput. Math. Appl., 61(2011), 2447-2455.

[5] L.C. Ceng, S.M. Guu, J.C. Yao, Finding common solutions of a variational inequality, a general system of variational inequalities, and a fixed-point problem via a hybrid extragradient method, Fixed Point Theory Appl. 2011, Art. ID 626159, 22 pp.

[6] L.C. Ceng, A. Latif, A.E. Al-Mazrooei, Hybrid viscosity methods for equilibrium problems, variational inequalities, and fixed point problems, Applicable Anal., 95(2016), 1088-1117.

[7] L.C. Ceng, Z.R. Kong, C.F. Wen, On general systems of variational inequalities, Comput. Math. Appl., 66(2013), 1514-1532.

[8] L.C. Ceng, A. Petruşel, J.C. Yao, Relaxed extragradient methods with regularization for general system of variational inequalities with constraints of split feasibility and fixed point problems, Abstr. Appl. Anal. 2013, Art. ID 891232, 25 pp.

[9] L.C. Ceng, C.Y. Wang, J.C. Yao, Strong convergence theorems by a relaxed extragradient method for a general system of variational inequalities, Math. Methods Oper. Res., 67(2008), no. 3, 375-390.

[10] L.C. Ceng, M.M. Wong, Relaxed entragradient method for finding a common element of systems of variational inequalities and fixed point problems, Taiwanese J. Math., 17(2013), no. 2, 701724 .

[11] L.C. Ceng, J.C. Yao, Relaxed and hybrid viscosity methods for general system of variational inequalities with split feasibility problem constraint, Fixed Point Theory Appl., 43(2013), 50 pp.

[12] K. Goebel, W.A. Kirk, Topics in Metric Fixed-Point Theory, Cambridge University Press, Cambridge, 1990.

[13] J.S. Jung, A general composite iterative method for strictly pseudocontractive mappings in Hilbert spaces, Fixed Point Theory Appl., 173(2014), 21 pp.

[14] A. Latif, D.R. Sahu, Q.H. Ansari, Variable KM-like algorithm for fixed point problems and split feasibility problems, Fixed Point Theory Appl., 211(2014).

[15] J.L. Lions, Quelques Méthodes de Résolution des Problèmes aux Limites Non Linéaires, Dunod, Paris, 1969.

[16] G. Marino, H.K. Xu, A general iterative method for nonexpansive mappings in Hilbert spaces, J. Math. Anal. Appl., 318(2006), 43-56.

[17] G. Marino, H.K. Xu, Weak and strong convergence theorems for strict pseudo-contractions in Hilbert spaces, J. Math. Math. Appl., 329(2007), 336-346.

[18] N. Shioji, W. Takahashi, Strong convergence of approximated sequences for nonexpansive mappings in Banach spaces, Proc. Amer. Math. Soc., 125(1997), no. 12, 3641-3645.

[19] M. Tian, A general iterative algorithm for nonexpansive mappings in Hilbert spaces, Nonlinear Anal., 73(2010), 689-694.

[20] R.U. Verma, On a new system of nonlinear variational inequalities and associated iterative algorithms, Math. Sci. Res. Hot-Line, 3(1999), no. 8, 65-68.

[21] I. Yamada, The hybrid steepest-descent method for variational inequality problems over the intersection of the fixed-point sets of nonexpansive mappings, in: Inherently Parallel Algorithms in Feasibility and Optimization and Their Applications, edited by D. Butnariu, Y. Censor and S. Reich, North-Holland, Amsterdam, Holland, 2001, 473-504.

[22] H.K. Xu, Iterative algorithms for nonlinear operators, J. London Math. Soc., 66(2002), no. 2, 240-256

[23] H.K. Xu, T.H. Kim, Convergence of hybrid steepest-descent methods for variational inequalities, J. Optim. Theory. Appl., 119(2003), no. 1, 185-201.

[24] Y. Yao, Y.C. Liou, S.M. Kang, Approach to common elements of variational inequality problems and fixed point problems via a relaxed extragradient method, Comput. Math. Appl., 59(2010), 3472-3480.

Received: February 1st, 2015; Accepted: October 13, 2015. 